\title{
PENGARUH ORGANIZATIONAL COMMITMENT TERHADAP WORK ENGAGEMENT PADA PEKERJA DI BIDANG PENGEMBANGAN TEKNOLOGI INFORMASI
}

\author{
Dian Bagus Mitreka Satata \\ Program Studi Magister Psikologi, Universitas Muhammadiyah Malang \\ Email:dbagusms@webmail.umm.ac.id
}

Masuk : 28-09-2020, revisi: 27-10-2020, diterima untuk diterbitkan : 31-10-2020

\begin{abstract}
This study aims to examine the effect of organizational commitment toward work engagement on information technology development-based workers. Organizational commitment is an attitude of full loyalty, dedication, willingness, and interest shown by workers in an organization. Work engagement is a positive psychological condition that an individual has about the organization and the values in it. There were 32 subjects studied $(84 \%$ male, $16 \%$ female) by purposive sampling technique. The instruments used were the Organizational Commitment Questionnaire (OCQ) and Utrecht Work Engagement Scale (UWES). Analysis using a linear regression test between variables. The results show that organizational commitment does not significantly influence the level of work engagement in workers in the field of information technology development.
\end{abstract}

Keywords: organizational commitment, work engagement, information technology

\begin{abstract}
ABSTRAK
Penelitian ini bertujuan untuk menguji pengaruh organizational commitment terhadap work engagement pada pekerja berbasis pengembangan teknologi informasi. Organizational commitment merupakan sikap penuh loyalitas, dedikasi, kerelaan, dan ketertarikan yang ditunjukkan oleh pekerja pada sebuah organisasi. Work engagement merupakan kondisi psikologis seseorang secara positif yang dimiliki individu terhadap organisasi dan nilai-nilai di dalamnya. Terdapat 32 subjek (84\% laki-laki, 16\% perempuan) dengan teknik pengambilan sampel purposive sampling. Instrumen yang digunakan adalah Organizational Commitment Quistionnaire (OCQ) dan Utrecht Work Engagement Scale (UWES). Analisis dengan menggunakan uji regresi linear antar variabel. Hasil menunjukkan bahwa organizational commitment tidak berpengaruh signifikan terhadap tingkat work engagement pada pekerja di bidang pengembangan teknologi informasi.
\end{abstract}

Kata Kunci: organizational commitment, work engagement, teknologi informasi

\section{PENDAHULUAN \\ Latar Belakang}

Dewasa ini banyak sekali persaingan bisnis antar perusahaan sehingga kualitas barang dan jasa perlu ditingkatkan, untuk itu perlunya SDM (Sumber Daya Manusia) sangat berperan dalam memproduksi barang dan jasa di bidang teknologi informasi (Rothman \& Cooper, 2008). Namun sekarang ini banyak sekali karyawan yang enggan untuk menetap pada satu perusahaan dengan berbagai motivasi. Untuk saat ini individu sering mencari pekerjaan yang dianggapnya lebih menguntungkan dari berbagai segi pribadi atau kebutuhan, namun bagi perusahaan hal tersebut bisa menjadi ancaman karena SDM yang kurang berkomitmen dalam perusahaan akan menjadi kurang efektif dalam menjalankan sistem organisasi sehingga menghambaat sistem produksi (Otoo, 2018).

Lalu di dalam sebuah organisasi saat ini pekerja dituntut dapat berkerja sesuai dengan prosedur yang sesuai dengan visi misi organisasi perusahaannya. Pekerja yang memiliki komitmen yang tinggi akan lebih termotivasi untuk hadir dalam organisasi dan berusaha mencapai tujuan (Steers, 1988). Hal ini menyangkut sebuah komitmen yang mendasar bahwa organisasi kerja harus selalu aktif pada tugas sesuai fungsi dalam pencapaian tujuan bersama. Work engagement merupakan 
suatu kondisi atau derajat yang menunjukkan seberapa besar seseorang benar-benar menghayati peran kerjanya (Saks, 2006) di bidang teknologi informasi.

Ketika pandemi melanda saat ini seorang pekerja harus tetap bekerja sesuai target dan kebutuhan perusahaan, namun hal ini tidak dipungkiri bahwa jam kerja yang relatif fleksibel terkadang membuat beberapa pekerja mengeluh karena terlalu banyak tugas yang tidak terorganisir dengan baik dan di luar jam kerja (Bakker \& Demerouti, 2007). Maka peran organizational commitment berlaku bagi karyawan dilihat dari segi normatif yang dimana seorang pekerja harus patuh pada perintah SOP (Standar Operasional Prosedur). Tingginya tingkat work engagement ditentukan oleh seberapa kuat komitmen yang dibangun pekerja untuk memenuhi kebutuhannya (Allen \& Meyer, 1990) terutama pada perkembangan teknologi informasi sekarang ini.

Temuan hasil penelitian menyebutkan implikasi dari segi psikologis dari work engagement dapat mempengaruhi kinerja karyawan yang baik (Salanova, et al., 2005), meningkatkan kebahagiaan serta kesejahteraan pada subjek karyawan bus di Zimbabwe (Buitendach et al., 2016). Hasil temuan lain menyebutkan tingkat engaged tinggi dapat menekan gejala depresi karena kepuasan hidup serta berkembangnya nilai fisik, kognitif, dan emosional (Salanova, Agust, \& Peiro, 2005), serta life satisfaction (Hanaken \& Schaufeli, 2012). Oleh karena itu teknologi informasi merubah cara berpikir SDM untuk lebih berkembang dan mampu beradaptasi dengan teknologi informasi untuk lebih maju dalam berkomunikasi (Cascio \& Montealegre, 2016).

Dari hasil sejumlah penelitian ditemukan bahwa work engagement dipengaruhi oleh beberapa faktor internal seperti pengalaman hidup tiap individu (Koyuncu, Burke \& Fiksenbaum, 2006), job performance secara intensif pada bidang pekerjaannya (Lazauskaite, Urbanaviciute \& Balsiene, 2018), quality of work life (Alqarni, 2016), serta evaluasi diri (Oliveira \& Rocha, 2016). Sedangkan faktor eksternal meliputi dukungan keluarga (Xanthopoulou et al., 2008), organizational commitment (Walden, Jung \& Westerman, 2017).

Pada hasil penelitian sebelumnya tidak terdapat pengaruh antara komitmen organisasi terhadap kinerja karyawan (Rahardja \& Simanjuntak, 2017). Namun pada penelitian lain menyebutkan terdapat pengaruh positif antara organizational commitment terhadap sikap perubahan organsisasi di United emirat Arab (Yousef, 2016). Teknologi informasi memiliki implikasi besar bagi perkembangan perusahaan untuk mengorganisir SDM agar sistem dapat berjalan dengan baik, banyak sekali keuntungan yang dihasilkan dari penggunaan teknoloni saat ini (Cascio \& Montealegre, 2016). Banyak perubahan dari berkembangnya teknologi informasi terutama bagi bidang organisasi dan industri saat ini dan ke depannya (Velasquez, 2010).

Dari hasil temuan tersebut maka peneliti perlu lebih dalam menyelidiki pengaruh organizational commitment sebagai variabel independen yang memiliki pengaruh terhadap tingkat work engagement pada pekerja di bidang teknologi informasi, terlebih ketika pandemi saat ini yang lebih intensistas pekerjaan lebih "menekan" karena kebutuhan akan teknologi informasi yang berkembang. Oleh karena itu tujuan penelitian ini untuk mengkaji pengaruh antara organizational commitment dengan work engagement pada pekerja di bidang pengembangan teknologi informasi di saat pandemi. Manfaat dalam penelitian ini agar para praktisi di bidang teknologi informasi dapat meningkatkan komitmen organisasi dan menumbuhkan engaged dalam bekerja serta menambah kajian di bidang psikologi industri dan organisasi dengan perkembangan teknologi informasi. 


\section{Organizational Commitment}

Komitmen terhadap organisasi adalah variabel sikap dalam konteks kerja terdapat beberapa definisi dari komitmen namun semuanya terkait dengan kelekatan individu pada organisasi (Spector, 2000). Organizational commitment merupakan kondisi dimana individu sangat tertarik terhadap tujuan, nilai-nilai, dan sasaran organisasinya (Steers, 1988). Organizational commitment artinya lebih dari sekedar keanggotaan formal, karena meliputi sikap menyukai organisasi dan kesediaan untuk mengusahakan tingkat upaya yang tinggi bagi kepentingan organisasi demi pencapaian tujuan.

Allen \& Meyer (1990) menyatakan bahwa individu yang memiliki komitmen tinggi akan bekerja penuh dengan dedikasi, karena individu yang memiliki komitmen tinggi menganggap bahwa hal paling penting yang harus dicapai adalah pencapaian tugas dalam organisasi. Individu yang memiliki organizational commitment yang tinggi juga memiliki pandangan yang positif dan akan melakukan yang terbaik untuk kepentingan organisasi.

Hal ini membuat Individu memiliki keinginan untuk memberikan tenaga dan tanggung jawab yang lebih menyokong kesejahteraan dan keberhasilan organisasi tempatnya bekerja. Gambaran mengenai organizational commitment dikemukakan oleh Meyer \& Allen (2004), bahwa organizational commitment dapat diidentifikasi dari tiga jenis komitmen yaitu afektif, normatif, dan continuance. Komitmen di dalam organisasi menentukan persaan dari individu dalam mengidentifikasi keterlibatannya dalam suatu bidang organisasi sehingga akan menimbulkan rasa ikut memiliki terhadap organiasinya.

Secara umum, gambaran tersebut menunjukkan bahwa para karyawan yang memiliki afektif yang kuat akan tetap tinggal bersama organisasi dikarenakan mereka ingin tinggal. Para karyawan yang memiliki continuance yang kuat tetap tinggal bersama organisasi dikarenakan mereka memang harus tinggal bersama organisasi, dan para karyawan yang memiliki normatif yang kuat dikarenakan mereka merasa bahwa mereka harus tinggal dan taat terhadap aturan. Jadi dapat disimpulkan bahwa organizational commitment merupakan sikap penuh loyalitas, dedikasi, kerelaan, dan ketertarikan yang ditunjukkan oleh pekerja pada sebuah organisasi dalam mewujudkan serta mencapai nilai, sasaran, dan tujuan organisasi.

\section{Work Engagement}

Work engagement merupakan kondisi psikologis seseorang terdiri atas aspek vigor, dedication, absorption. Vigor adalah energi, daya tahan secara fisik dan mental, kesediaan untuk berusaha, ketekunan menghadapi kesulitan. Dedication merupakan antusias, inspiratif, kebanggaan, merasa tertantang dalam pekerjaan. Absorption yaitu selalu konsentrasi pada pekerjaan, gembira, mencintai pekerjaannya, tidak terpisah-kan dengan pekerjaan (Schaufeli \& Bakker, 2003).

Work engagement merupakan suatu keadaan ketika manusia merasa dirinya menemukan arti diri secara utuh, memiliki motivasi dalam bekerja, maupun menerima dukungan orang lain secara positif serta mampu bekerja secara efektif dan efisien di lingkungan kerjanya (Benthal, 2006). Work engagement lebih daripada keadaan sesaat dan spesifik, mengacu pada keadaan yang begerak tetap meliputi aspek kognitif dan afektif yang tidak fokus pada objek, peristiwa, individu atau perilaku tertentu (Schaufeli \& Martinez, 2002). Schaufeli, et al. (2002) mendefinisikan work engagement sebagai positivitas, pemenuhan, kerja dari pusat pikiran yang dikarakteristikkan. 
Kahn (1990) menyebutkan bahwa dalam work engagement, seseorang bekerja dan mengekspresikan dirinya secara fisik, kognitif, dan emosi selama mereka bekerja. Jadi beberapa penjelasan di atas dapat disimpulkan work engagement merupakan keyakinan karyawan dalam bekerja dengan mengekspresikan dirinya secara total baik secara fisik, kognitif, afektif dan emosional.

\section{Organizational Commitment dan Work Engagement}

Pada dasarnya work engagement dibentuk oleh dua konsep teori yaitu komitmen organisasi dan citizenship behaviour, yaitu perilaku individu pekerja yang bersedia melakukan kegiatan melebihi tugas dan fungsi pokoknya untuk mewujudkan produktivitas dan kualitas kerja (Robbins, 2006). Organizational commitment merupakan hal yang penting untuk menghasilkan kinerja dan work engagement memiliki hubungan yang kuat dengannya (Field \& Buitendach, 2011). Pengaruh komitmen dengan work engagement dipengaruhi oleh modal psikologis seperti kepercayaan diri, self-efficay, rasa optimis, hope, resiliensi sehingga mampu mengontrol diri untuk dapat berkomitmen serta memberikan dampak pada lingkungan (Schaufelli et al, 2002).

Merujuk pada teori determinasi diri yaitu dengan mengembangkan sumber daya manusia (SDM) secara mandiri dan psositif yang berasal dari motivasi untuk menuju kesejahteraan (Ryan \& Deci, 2000). Teori determinasi diri mendorong individu untuk melakukan tindakan yang diinginkannya yang berasal dari dalam diri, sehingga mampu mengidentifikasi dan mencapai tujuan berdasarkan pengetahuan dan penilaian individu terhadap dirinya sendiri. Dalam hal ini tujuan organisasi mampu menjadi tolak ukur individu dalam mengembangakan potensi yang dimiliki sehingga mampu engaged terhadap organisasinya.

Perspektif teori lain mengatakan bahwa proses psikologis seperti merasa berkewajiban, bermakna dan suasana hati positif sebagai SDM kerja yang berkomitmen sehingga memunculkan work engagement (Albrecht, 2013). Pada hasil temuan penelitian sebelumnya menyebutkan bahwa terdapat hubungan antara organizational commitment dengan work engagement (Ahuja \& Gupta, 2014). Pada penelitian Zhang et al., (2015) work engagement memediasi pengaruh negatif dari organizational commitment terhadap turnover intention, sehingga semakin tinggi tingkat enggaged karyawan semakin berkurang turnover intentionnya dan semakin kuat tingkat komitmen pada organisasinya.

Penelitian lain juga memiliki hubungan positif antara organizational commitment dengan work engagement (Walden et al., (2017). Hasil temuan sebelumnya mengungkapkan bahwa orfganizational commitment memiliki hubungan yang positif dengan work engagement (Field \& Buitendach, 2011). Sehingga dapat disimpulkan pada temuan penelitian sebelumnya bahwa organizational commitment berpengaruh pada tingkat work engagement pada karyawan berdasarkan penelitian yang sudah ada.

\section{METODE PENELITIAN}

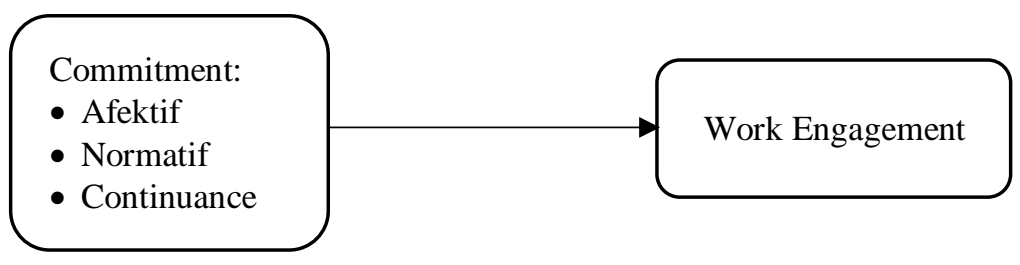

Bagan 1. Kerangka pemikiran 
Hipotesis pada penelitian ini adalah sebagai berikut:

$\mathrm{H}_{0}$ : Tidak terdapat pengaruh organizational commitment terhadap work engagement

$\mathrm{H}_{1}$ : Terdapat pengaruh organizational commitment terhadap work engagement

\section{Partisipan dan Prosedur Penelitian}

Pengaruh antar variabel dapat digambarkan dalam rancangan penelitian pada bagan 1. Subjek dalam penelitian ini adalah karyawan yang tergabung dalam organisasi kerja dengan masa kerja lebih dari satu tahun dengan total subjek 32 pada beberapa perusahaan di bidang pengembangan teknologi informasi PT. XYZ. Teknik pengambilan sampel yang digunakan dalam penelitian ini adalah purposive sampling, artinya individu yang telah memenuhi kriteria-kriteria sesuai dengan ketentuan dan pertimbangan peneliti (Sugiyono, 2013).

\section{Instrumen Penelitian}

Skala pengukuran merupakan kesepakatan yang digunakan sebagai acuan untuk menentukan panjag pendeknya interval yang ada dalam alat ukur, sehingga alat ukur tersebut bila digunakan dalam pengukuran akan menghasilkan data kuantitatif (Sugiyono, 2013). Instrumen atau skala psikologi digunakan untuk mengungkap data mengenai atribut psikologis yang dapat dikategorikan sebagai variabel-variabel (Azwar, 2014).

Work engagement menggunakan skala Utrecht work engagement scale (UWES) dari Schaufeli \& Bakker (2003). UWES menggunakan tiga karakteristik yaitu vigor, dedication, dan absorption dengan koefisien 0,934 yang terdiri dari 17 aitem. Berikut contoh dari item UWES "Ketika saya bangun di pagi hari, saya merasa ingin bekerja", seluruh pernyataan diisi menggunakan skala likert dengan pilihan jawaban "tidak pernah", "jarang", "kadang-kadang", "selalu", dan "sering sekali”.

Organizational commitment diukur dengan menggunakan alat ukur organizational commitment questionnaire (OCQ) yang disusun oleh Mowday, Steers, \& Porter pada tahun 1979, kemudian diadaptasi dan dikembangkan oleh Meyer dan Allen (2004). Skala OCQ menggunakan tiga aspek afektif, normatif dan continuance dengan koefisien 0,849 yang terdiri dari 18 item. Contoh dari item OCQ "Saya ingin menghabiskan sisa karir saya di perusahaan ini", seluruh pernyataan diisi menggunakan skala likert dengan pilihan jawaban "tidak pernah", "jarang", "kadangkadang", "selalu", dan "sering sekali".

Teknik analisis data dalam penelitian ini menggunakan analisis regresi linier. Analisis regresi merupakan sebuah metode pendekatan untuk pemodelan hubungan antara satu variabel dependen dan satu variabel independen (Azwar, 2014).

\section{HASIL DAN PEMBAHASAN}

Terdapat subjek laki-laki 27 dan 5 (84\% dan 16\%), sehingga pekerja laki-laki lebih dominan dikarenakan tuntutan kerja yang begitu banyak serta menuntut pada waktu (deadline) dan hasil di bidang pengembangan teknologi informasi. Berdasarkan hasil data tabel 1 diperoleh nilai mean pada organizational commitment $(\mathrm{M}=55,03 ; \mathrm{SD}=11,07)$ sedangkan work engagement $(\mathrm{M}=$ $60,62 ; \mathrm{SD}=5,5)$ sehingga rata-rata hasil pengukuran variabel berada pada tingkat sedang.

Tabel 1. Nilai mean dan standar deviasi variabel penelitian $(n=32)$

\begin{tabular}{ccc}
\hline Variabel & M & SD \\
\hline OC & 55,03 & 11,07 \\
\hline WE & 60,62 & 5,5 \\
\hline
\end{tabular}


Hasil analisis regresi menunjukkan bahwa nilai sig. sebesar $\mathrm{p}=0,932$ yang menunjukkan bahwa nilai $\mathrm{p}>0,05$, sehingga dapat disebutkan bahwa tidak terdapat pengaruh yang signifikan antara organizational commitment terhadap work engagement pada pekerja di bidang pengembangan teknologi informasi.

Tabel 2. Hasil Uji Regresi

\begin{tabular}{cccc}
\hline & $\boldsymbol{\beta}$ & $\mathbf{p}$ & $\mathbf{R}_{\mathbf{2}}$ \\
\hline Model & - & - & 0,000 \\
\hline Constanta & - & 6,105 & - \\
\hline OC*WE & $-0,008$ & 0,932 & - \\
\hline
\end{tabular}

Berdasarkan uji tabel 2 menunjukkan bahwa tidak ada pengaruh signifikan antara organizational commitment dengan work engagement pada pekerja di bidang teknologi informasi $(\beta=-0,008 ; p$ = 0,932) sehingga $\mathrm{H}_{1}$ ditolak dan $\mathrm{H}_{0}$ diterima.

Hasil penelitian menunjukkan bahwa organizational commitment tidak berpengaruh signifikan terhadap work engagement pada pekerja di bidang pengembangan teknologi informasi. Temuan ini mengindikasikan bahwa pekerja di bidang pengembangan teknologi informasi bekerja berdasarkan lingkungan kerja dan gaji yang mendukung. Hasil ini didukung dari hasil penelitian bahwa organizational commitment memiliki pengaruh negatif terhadap work engagement (Ortiz, et al., 2013). Berdasarkan hal tersebut mengindikasikan bahwa pengaruh organisasi tidak memberikan efek positif bagi beberapa individu, dapat dijelaskan bahwa masing-masing individu lebih memilih untuk mengembangkan diri menjadi pekerja lepas (freelancer) tanpa terikat oleh organisasi.

Hasil dari penelitian tersebut sejalan dengan penelitian sebelumnya yang mengindikasikan bahwa terdapat tekanan dan stress kerja yang tidak sejalan sehingga berakibat konflik pada beberapa individu meskipun memiliki passion pada bidang yang digeluti (Suryani \& Yoga, 2018). Selain itu individu yang enggan berkomitmen dalam organisasi tidak ingin terikat secara "full time" sehingga individu mampu mengembangkan bisnis secara mandiri (Mustofa, 2018). Hasil studi menyebutkan seiring dengan perkembangan teknologi saat ini terutama berbasis internet serta media sosial, profesi freelancer mulai mendapat pengakuan (Anggrian \& Sumarlin, 2016). Menurut survei upwork dalam Future Workforce Report 2017 menyebutkan bahwa 84\% perusahaan di dunia menginginkan kerja sama dengan para freelancer karena memiliki ide yang segar dalam berkarya.

Namun hal ini berbeda dengan temuan sebelumnya bahwa terdapat hubungan positif antara organizational commitment dengan work engagement (Ahuja \& Gupta, 2014). Karyawan yang rendah terhadap rasa komitmen organisasinya karena memiliki tuntutan yang tinggi terhadap aturan dalam organisasinya. Hal ini menjadi dampak dari aturan yang terikat dan harus dipenuhi oleh setiap karyawan yang tergabung dalam organisasi perusahaan di bidang pengembangan teknologi informasi. Namun terdapat beberapa karyawan yang enggan berorganisasi namun cinta terhadap pekerjaannya, sehingga banyak pengembang teknologi informasi yang lebih memilih bekerja secara freelance daripada terikat oleh organisasi perusahaan.

Hal ini berdasarkan pengamatan dan wawancara terbuka terhadap beberapa karyawan yang pernah bekerja freelance dan saat ini tergabung dengan perusahaan, maka hal tersebut didukung oleh afektif pada masing-masing individu (Allen \& Meyer, 1990). Ditemukan bahwa laki-laki lebih banyak daripada perempuan yang bekerja di bidang teknologi informasi adalah berdasarkan 
worklife experience, dan konsistensi (Koyuncu et al., 2006) dikarenakan laki-laki lebih berorientasi pada jenjang karir kerja. Faktor lain yang menyebabkan karyawan enggan tergabung dalam organisasi perusahaannya karena tuntutan pekerjaan yang tuntutan kerja yang berat (Bakker \& Demerouti, 2007). Individu lebih memilih bekerja secara fleksibel tanpa harus berkomitmen dengan perusahaan yang dinaungi, namun mereka akan siap bila dibutuhkan dalam mengerjakan proyek (Cohen, 2017).

Biasanya perusahaan memiliki tarif yang relatif dengan standar perusahaan sehingga upah yang didapat tidak sebanding daripada secara freelance. Namun hal ini merupakan salah faktor yang bisa menjadi penyebab karyawan di bidang pengembangan teknologi informasi selalu berpindah pada perusahaan lain yang lebih menguntungkan. Faktor internal yang menyebabkan para pengembang teknologi informasi juga dipicu dari burnout yang pada masing-masing individu sehingga memilih jam kerja yang lebih fleksibel (Hanaken \& Schaufeli, 2012).

\section{KESIMPULAN DAN SARAN}

Berdasarkan hasil penelitian dan pembahasan yang telah diuraikan dapat disimpulkan bahwa tidak ada pengaruh organizational commitment terhadap work engagement pada pekerja di bidang pengembangan teknologi informasi. Dapat dikatakan bahwa organizational commitment tidak berpengaruh besar terhadap tingkat work engagement, namun dari hasil pengamatan observasi peneliti beberapa faktor bisa menjadi pertimbangan yang berpengaruh seperti; lingkungan kerja, dukungan sosial, partner kerja, passion, dan sebagainya. Penelitian ini masih sangat sederhana terkait faktor-faktor yang masih belum berpengaruh secara kesuluruhan terhadap tingkat work engagement selain dari organizational commitment pada pekerja. Serta subjek yang masih terbatas dikarenakan masa pandemi Covid-19 sehingga peneliti masih terbatas dalam mendapatkan subjek penelitian.

\section{Ucapan Terima Kasih}

Peneliti mengucapkan terima kasih kepada semua pihak yang telah mendukung dan terlibat selama pelaksanaan penelitian ini sehingga penelitian ini dapat berjalan dengan lancar.

\section{REFERENSI}

Ahuja, A., \& Gupta, S. (2014). Organizational commitment and work engagement as a facilitator for sustaining higher education professionals. International Journal of Recent Technology and Enggineering, (7), 1846-1851.

Albrecht, S. L. (2013). Work engagement and the positive power of meaningful work. Advances in Positive Organizational Psychology, 1(2002), 237-260. doi: 10.1108/S2046410X(2013)0000001013

Alqarni, S. A. Y. (2016). Quality of work life as a predictor of work engagement among the teaching faculty at king abdulaziz university. International Journal of Humanities and Social Science, 6(8), 118-135.

Allen, N. J, \& Meyer, J. P. (1990). The measurement and antecendent of affective continuance and normative commitment to the organization. Journal of Occupational Psychology, 63, $1-8$.

Anggrian, W. M. \& Antonious W. S. (2016). Pengaruh komitmen tenaga kerja lepas terhadap motivasinya dalam perusahaan keluarga di sektor informal. Jurnal Manajemen Teknologi, 15(2), 139-153.

Azwar, S. (2014). Metode Penelitian. Yogyakarta : Pustaka Pelajar.

Bakker, A. B., \& Demerouti, E. (2007). The job demands-resources model: state of the art. Journal of Managerial Psychology, 22(3), 309-328. 
Benthal, P., Wellins, R.S., and Phelps, M. (2006). Employee Engagement: The Key to Realizing Competitive Advantage. Development Dimensions International, Inc.

Cascio, W. F., \& Montealegre, R. (2016). How technology is changing work and organizations. The Annual Review of Organizational Psychology and Organizational Behavior, 3, 349375.

Cohen, Nicole S. (2017). Ventue labor: freelancing as the good life?. International Journal of Communication, 11.

Field, L. K., \& Buitendach, J. H. (2011). Happiness, work engagement and organizational commitment of support staff at a tertiary education institution in South Africa. SA Journal of Industrial Psychology, 37(1), 110.

Hanaken, J. J. \& Schaufeli, W. B. (2012). Do burnout and work engagement predict depressive symptoms and life satisfaction? A three-wave seven-year prospective study. Journal of Affective Disorders, 141, 415-424.

Kahn, W. A. (1990). Psychological conditions of personal engagement and disengagement at work. Academy of Management Journal, 33.

Koyuncu, M., Burke, R.J. \& Fiksenbaum, L. (2006). Work engagement among women managers and professionals in a Turkish bank: potential antecedents and consequences. Equal Opportunities International, 25, 299-310.

Lazauskaite-Zabielske, J., Urbanaviciute, I., \& Balsiene, R. R. (2018). From psychosocial working environment to good performance: the role of work engagement. Baltic Journal of Management, 13(2), 236-249. doi:10.1108/bjm-10-2017-0317.

Meyer, J. P., \& Allen, N. J. (2004). TCM employee commitment survey academic users guide. University of Western Ontario.

Mustofa. (2018). Pekerja lepas (freelancer) dalam dunia bisnis. Jurnal Mozaik, 10(1), 19-25.

Oliveira, L., B \& Rocha, C J. (2016). Work engagement: individual and situational antecedents and its relationship with turnover intention. Review Business Management. 19 (65) 415 431.

Otoo, F. N. K. (2018). Human resource development (HRD) practices and banking industry effectiveness the mediating role of employee competencies. European Journal of Training and development. DOI 10.1108/EJTD-07-2018-0068.

Ortiz, D. A. C., Lau, Elaine W. K. \& Qin, H. (2013). Quantitative analysis of impacts of employee engagement on continuance and normative commitment. International Journal of Services and Standards, 8(4), 315-331.

Rahardja, A. \& Simanjuntak, A., (2017). Pengaruh motivasi kerjadan komitmen organisasi terhadap kinerja karyawan produksi PT. chatindo karya utama. Jurnal Agora, 6(1).

Robbins, S. P., (2006). Perilaku Organisasi, Edisi Lengkap. Jakarta. PT. Indeks Kelompok Gramedia.

Rothman, I., \& Cooper, C. (2008). Organizational and Work Psychology Topic in Applied Psychology. Hodder Education Part of Hachette Livre UK.

Ryan, R. M., \& Deci, E. L. (2000). Self determination theory and the facilitation of intrinsic motivation, social development, and well-being. American Psychologist. 55(1) 68-78. doi: 10.1037/0003-066X.55.1.68

Schaufeli, W. B., Salanova, M., Gonzalez-Roma, V., \& Bakker, A. B. (2002). The measurement of engagement and burnout: a two samples confirmatory factor analytic approach. Journal of Happiness Studies, 3, 71-92.

Schaufeli, W. B., Martínez, I. M., Pinto, A. M., Salanova, M., \& Bakker, A. B. (2002). Burnout and engagement in university students. Journal of Cross-Cultural Psychology, 33(5) 464481. 
Schaufeli, W \& Bakker, A. (2003). UWES (Utrecht Work Engagement Scale). Occupational Health Psychology Unit. Utrecht University.

Salanova, M., Agut, S. \& Peiro, J. M. (2005). Linking organizational resources and work engagement to employee performance and customer loyalty : the mediation of service climate. Journal of Applied Psychology by The American Psychology Association, 90(6) $1217-1227$.

Saks, A. M. (2006). Antecedents and consequences of employee engagement. Journal of Managerial Psychology, 21, 600-619.

Steers, R. M. 1988. Introduction to Organizational Behavior. Chicago. Scatt Foksman and Company.

Sugiyono. (2013). Statistika Untuk Penelitian. Bandung. Alfabeta.

Suryani, N. K. \& Yoga, G. A. D. (2018). Konflik dan stres kerja dalam organisasi. Jurnal Widya Manajemen, 1(1), 99-113.

Velasquez, D. L. (2010). Impact of technology on organizational change in public libraries: a qualitative study. Advances in Library Administration and Organization, 29, 107-183.

Walden, J., Jung, E. H., \& Westerman, C. Y. K. (2017). Employee communication, job engagement, and organizational commitment: a study of members of the millennial generation. Journal of Public Relations Research. 10.1080/1062726X.2017.1329737

Xanthopoulou, D., Baker, A. B., Heuven, E., Demerouti, E., \& Schaufeli, W. B. (2008). Working in the sky: A diary study on work engagement among flight attendants. Journal of Occupational Health Psychology, 13(4), 345-356. https://doi.org/10.1037/10768998.13.4.345.

Yousef, D. A. (2016). Organizational Commitment, Job Satisfaction and Attitudes toward Organizational Change: A Study in the Local Government. International Journal of Public Administration, 40(1), 77-88.

Zhang, J. C., Ling, W. L., Zhang, Z. Y. \& Xie, J. (2015). Organizational commitment, work engagement person-supervisor fit, and turnover intention: A total effect moderation model. Society of Personality Research, 43(10), 1657-1666. 